\title{
GENESIS OF IDEOLOGIES THROUGH THE PRISM OF INTENSIVE DEVELOPMENT OF INFORMATION AND COMMUNICATION TECHNOLOGIES
}

\author{
Sergey S. Shestopal,. ${ }^{1}$ \\ Alexey Y. Mamychev . ${ }^{2}$ \\ Svetlana V. Kachurova ${ }^{3}$ \\ Evgeniy V. Kachurov ${ }^{4}$
}

\begin{abstract}
The new milestones should be expected with the formation of a digital civilization, in the development of all institutions of social relations. Within the mainstream of present study, the authors aim to trace the evolution of ideological institutions, to describe the potential threats and risks for a government institution associated with the introduction of digital technologies resulted in the modern transformation of the value and regulatory foundations of society through the new challenges of digital transformation of international, state-law and social relations. Presently, the two definitions are constituting the
\end{abstract} concept of ideology. The first one is claiming the "false consciousness" $(\mathrm{K}$. Marx); the second one -"enlightened false consciousness" (P. Sloterdayk). This constructional evolution of the relationship between phenomenology and ideology that is in the center of the study of numerous scholars exists over a century. Along with this story, the philosophy itself as a science had been considerably changed. Such a sharp deviation of the various theories of knowledge of the last two centuries was caused exclusively by the practical orientation of ideological consciousness. The present study is focused on the

\footnotetext{
${ }^{1} \mathrm{PhD}$ in Legal Sciences, Associate Professor of Law Department, Vladivostok State University Of Economics And Service, Vladivostok, Russia. Postdoctoral researcher European Union Law Department, Yaroslav Mudryi National Law University, Kharkov, Ukraine. Email: ss.shestopal@ ya.ru. ORCID: 00000002-8490-2006

${ }^{2}$ Doctor habil. In political science, $\mathrm{PhD}$ in legal science, head of the laboratory of political and legal research, Lomonosov Moscow State University; Department of Theory and History of Russian and Foreign Law, Vladivostok State University of Economics and Service, Vladivostok, Russia.mamychev@yandex.ru ORCID 0000-0003-1325-7967.

${ }^{3} \mathrm{PhD}$ in Philosophy, Associate Professor of Philosophy Department, Yaroslav Mudryi National Law University, Kharkov, Ukraine. Email: kachurove@mail.ru. ORCID: 0000-0002-3103-3142.

${ }^{4} \mathrm{PhD}$ in Philosophy, Zhukovsky's National Aerospace University. "Kharkiv Aviation Institute” Kharkov. Ukraine. Email: kachurove@mail.ru. https://orcid.org/0000-0002-1166-7359
} 
clarification of this urgent for modern political philosophy issues being strongly influenced by intensive development of information and communication technologies.

Keywords: state, law, ideology genesis, digital transformation of society, phenomenology, law, naive consciousness, conditioned consciousness, default, cynicism.

\section{INTRODUCTION}

The widespread influence of modern digital information technologies generates the transformation of socioeconomic, political, and legal development and requires a special, close study of the influence of these factors on public consciousness, valueregulatory and ideological foundations of modern society. The new milestones should be expected with the formation of a digital civilization, in the development of all institutions of social relations. Within the mainstream of present study, the authors aim to trace the evolution of ideological institutions, describe the potential threats and risks for a government institution associated with the introduction of digital technologies resulted in the modern transformation of the value and regulatory foundations of society.

Today in Russia the topic of state ideology is raised even more often than in the late 80 s - early 90s. last century, when the Russian society was imposed on the perception of ideology (and "ideology" as a social and spiritual phenomenon) as a dangerous social phenomenon. This argument was decisive in the destruction of Soviet ideology, launching the demolition of the entire Soviet state began at that time. However, without building a coherent model of a new state ideology, we are faced with new challenges of digital information reality, modern methods of transferring information, shaping public opinion, public administration

Modern discussions are caused by the fact that the formation of a new Russia requires a solution to the issue of state ideology. And this is not a paradox, this is a law known since biblical times: "Every kingdom, He says, divided within itself, will be empty, and every city or house, if divided, will soon be destroyed" (Matthew 12: 25-26). The state cannot exist without its own ideology, since it is thanks to it that it unites people into a single whole. 
Arguments and voices about the need to establish a state ideology in Russia are sounding more and more insistently: “... without a new ideology and a positive social practice transforming the world based on it, Russia and its allies have no future" (Ballaev,1989). But the country's legal system is catastrophically not keeping up with the pace of ideological information discourse. We continue to be guided by the 13th Article of The Constitution of the Russian Federation, which proclaims "ideological diversity" and prohibits "state ideology". The question of the advisability of constitutional consolidation of state ideology, which is associated with the need (and requirements) to revise the content of Art. 13 of the Constitution of the Russian Federation, denying the state ideology as such. Clarification (change) of certain provisions of the Constitution is not only permissible but eventually and inevitable. Social reality is changing and it is quite natural that the norms regulating the life of society must undergo changes. The Constitution, as you know, is a legal document of direct action and society is vitally interested in its adequacy to the new social realities. In other words, the Constitution is not
Scripture. Changing it is common and necessary over time. What exactly should change in the understanding of the role of ideology in modern Russia and in the attitude of the state and society towards it?

Possibly it makes sense to turn once again to the interpretation of the essence, the development of ideology, and ideological systems. Although in modern social science there is no common understanding of the notion "ideology" shared by most researchers. A significant part of scientists sees it as a theoretical construct that reflects the basic values, attitudes, and goals shared and pursued by the overwhelming majority of the country's citizens and supported by the state.

In spite of such diversity of treatments, in modern society, ideology performs many functions: educational, socializing, mobilization, controlling, ideological, and moral protection of society. "Ideology, defining the goals of politics, forms the guidelines for political activity, chooses the means of its implementation, mobilizes broad strata to participate in the implementation of politics" (New Philosophical Encyclopedia. M., 2010). 
At the same time, it should be pointed out once again that there is no common point of view on this problem in the expert community. Therefore, in this part of our further research, we turn to phenomenology in order to understand the essential content and meaning of ideological systems.

\section{CRIME NOVEL" OF PHENOMENOLOGY AND IDEOLOGY}

In the beginning, nothing foreshadowed a complication in the relationship between the two "logics": a phenomenon and an idea. The initial unity of their subject, structure, and tasks is striking until now ${ }^{5}$. And they had aroused almost simultaneously and had been occupied with the same thing - the being of consciousness ${ }^{6}$. The philosophical discipline called the "phenomenology" also had been occupied with the same "sublime" (S. Zhizhek) object of ideology. True, they dealt with this very consciousness in different ways. Phenomenology, as a

\footnotetext{
${ }^{5}$ For comparison, you can look at least at the contents of the "Foundations of ideology" by de Tracy (1800) and the "Phenomenology of the spirit" by Hegel (1807).

6 Although in the German version, as Husserl noted, "all consciousness is" consciousness of "" ("Bewusstseins von") ”[6, p. 12].
}

child specialization of the philosophy, tried to answer the question: “consciousness - what is it?" In other words, phenomenology just wanted to understand it. Ideology, having social practice (politics) in its sights, claimed otherwise. Ideology tries to influence this very consciousness, to change it according to its own design ${ }^{7}$

It seemed that even with such a distribution of roles, everything could have been good. It is as good as in a wellestablished production, when one side, theoretical, could prepare ideal samples for the subsequent application of the second, practical $^{8}$. It's as good as in a love story, when touching and tender relationships last forever, successfully overcoming all life's troubles. At least Hegel, one of the founders of classical phenomenology, mentioning, as far as we know, only once the word "ideology" did not put any negative meaning into it (Hegel,2019, p. 665).

Everything could have worked out well, but it didn't work out. After the Second World War, when the three

\footnotetext{
${ }^{7}$ In this sense, the 11th thesis on Feuerbach of K. Marx is the real manifesto of ideology.

8 And this, of course, with perfectly good intentions and to the universal happiness of mankind!
} 
major areas of modern ideology were completely determined (and not only defined in theory but also collided in historical being (Lyuks,2019, p. 31), it became clear to everyone that something had gone wrong. Something in their relationship began to resemble not a "love", but a "criminal" novel. A criminal "savour" started to blow from their union. Ideology has been accused of committing the worst crimes against humanity. Phenomenology, even worse, was called the ideological inspirer and organizer of the mentioned atrocities. The default ${ }^{9}$ of ideology, that is, the impossibility of fulfilling its obligations is perhaps the most striking phenomenon of our time! The search of the answer to the question: "How could this happen?" - became the main challenge for any research that wants to find an essential feature, or, as Hegel said, "shibboleth of time". ${ }^{10}$

Shibboleth $^{11}$ of our era. To answer it, we first add the main

\footnotetext{
${ }^{9}$ Now more and more often, the meaning of this concept goes beyond the boundaries of purely financial relations. It is applied to morality, personality, etc.

10 Then he saw this line differently. The shibboleth of time is, in his opinion, "a deep antithesis between philosophy and religion" [5, p. 231].

11 Or shibboleth (Hebrew שיבולת, "spike" or "flow") is a biblical expression, here it is used in the sense of "label", "identification mark". For
}

"puzzles" of the "criminal novel" of phenomenology and ideology that has developed and evolved over a century.

The consciousness of modern humans felt like a victim. The dead, material damage from the three world wars, and so on have been calculated. Naturally, they began to look for the guilty. First, a nationalistic ideology fell under suspicion, then a communist ideology. Everything seemed to be clear here: several camps, where people had been burned, and other camps where people had ben muzzled to death.

It was supposed that the third one (ideology) was liberal, just like a completely different one. It seemed that it was all "white and fluffy"12. But not at all. After the last events of the late XX and the beginning of the XXI centuries, the time when the same devastation, hunger, and death were on the heels of this kind of democracy... it has been

example, M.Yu. Lermontov describes Pechorin as follows: "The Hero of Our Time ... exactly a portrait, but not of one person: this is a portrait made up of the vices of our entire generation, in their full development." This character cannot be called positive or negative. Rather, he is a typical representative of his time.

12 By the way, the inventors of an institution called the "concentration camp" were the United States and England, the founding countries of the ideology of liberalism. 
undergone the doubts. With regret $^{13}$, they began to state that a liberal state in the international arena can be the same predator without any moral principles, like a fascist state on a national or communist one on a class one. That is, it suddenly turned out that liberal ideology was exactly the same totalitarian as the other two, only has a slightly different character. And that's all. In the intellectual sphere, for example, last year's scandal in connection with the publication in authoritative liberal magazines of articles with obviously absurd conclusions openly flattering this form of ideology testifies to this (Voronin, 2019). Thus, in relation to this kind of false consciousness, it became clear that liberal ideology would also expect at least "criminal prosecution".

To complete the picture of the organization of this very case, naturally, the last person involved was not found. There is a victim. There is a suspect. Need a detective. The latter, in order to achieve success, must be able (and it has already been said a hundred times) to think like a criminal. The question naturally arises: "What is that which thinks as ideology?"
We think «this and that»: mountains, rivers, gods and trees. But none of all this is "for myself." None of them is able to "percept" (none is “aware.") Everything is only "for us", for our consciousness. Yes, says Hegel, our consciousness presumes them (these things) to be something "in themselves" (entity). But, unfortunately, in this case too, "in itself" is the entity "for us" (phenomenon). This fact is the source of Kant's transcendentalism.

Only when we think not "this and that", but another consciousness, which is also "for ourselves", we think phenomenologically. Then and only then we think in much the same way as ideology. "Almost", which is very important, because in this case we are dealing with both identity and at the same time the opposite of these two "sisters" (two consciousnesses), or, as J. Derrida would say, we think of their "difference". They see a soul mate in each other.

The consciousness that we are exploring here with the help of our consciousness, our "for ourselves", does exist. It also exists "for itself"; V.I. Korotkikh basing on the material of

\footnotetext{
${ }^{13}$ After all, the last hope has disappeared!
} 
Hegelian phenomenology details the interaction of these issues as follows: "One should accurately distinguish between the consciousness of the author and the reader (I propose to designate it as" our consciousness", in Hegel, the boundaries of his" speech "are usually marked with" wir "(we), " für uns "(for us) $)^{14}$. Consciousness as an object of observation (I propose to designate it as "consciousness itself", in the text its "voice" is separated with the help of “es"(it), "ihm"(him)), and its "object" ... Hegel's text is as if "sewn" with these pronouns "( Korotkikh,2019). This is where the story of the novel of phenomenology and ideology, their "criminal" connection, will be born.

\section{Detective as a form of} understanding. It may seem that the use of the term "criminal novel" (detective story) as the intermediate-term between the extremes of "phenomenology" and "ideology" is just a literary method. However, it is very symptomatic that, firstly, all three "genres" historically appeared almost simultaneously ${ }^{15}$. Secondly, the author himself, speaking

\footnotetext{
${ }^{14}$ Here is mistreatment in the editorship of V.I. Korotkikh. In fact, he means here: one should distinguish, on the one hand, "the consciousness of the author and our consciousness", and consciousness as a subject of phenomenology on
}

of "sewing" with the moments "for ourselves" and "for us" of a classical phenomenological study, points to a detective (Korotkikh,2011, p. 360). Thirdly, before V.I. Korotkich and independently from him, P. Sloterdijk called the passion for detective stories "the most amazing feature of our cultural and moral situation" (Sloterdayk,2009, p. 458). And here the author of "Criticism of the Cynical Reason" makes a remark clarifying the meaning of not so much the criminal novel itself, but the final stage of the relationship between phenomenology and ideology. "Good detective novels - all without exception carry out the relativization of each individual crime. If the detective is the personification of the Enlightenment, then the criminal should be, respectively, the personification of immoralism, and the victim - the personification of morality. However, this scheme does not work regularly ... In the limiting case, onto the stage, a criminal is brought who, acting as if in the role of a provoked enlightener, only fairly punishes the victim for immorality"

the other. The fact that the first two consciousnesses are also different in turn is a special subject, which he considers elsewhere. ${ }^{15}$ At least in one century. 
(Sloterdayk,2009, ibid.). In our case, when the statement "ideology (criminal) - modern consciousness (victim) phenomenology (detective)" was formed, the transfer of responsibility came off not in one but in two directions at once. Both the victim and the detective received the blame. All three modern political ideologies (liberalism, nationalism, and communism) elude retribution in an eccentric way. They shift the negative meaning of their name onto phenomenology (!), that is, onto a detective, to someone who was supposed to be their whistleblower and accuser. "In tradition, philosophical and metaphysical systems began to fall under the rubric of ideology as specific ontologies, as derivatives of various kinds of structures. The logical analysis (criticized by Herbert Marcuse in the "One-Dimensional Man" philosophy of L. Wittgenstein) was also charged with ideology, despite the reduction of ontological and epistemological assumptions regarding subjectivity and lack of ethical issues. If E. Husserl's phenomenology was interpreted by representatives of the school of Soviet dialectical materialism as a kind of subjective idealism, then M. Heidegger's philosophy, mainly in the existential aspect, was understood as a version of bourgeois mysticism. The genius of $\mathrm{K}$. Marx played a cruel joke with himself: K. R. Popper places K.Marx's philosophy along with the philosophies of G. V. F. Hegel and F. Nietzsche as false prophets of "totalitarian ideologies" ") Yur'ev,2007)

The author of this fragment is reasonably correct. Here the fact of "infection" of modern forms of philosophy with ideology is properly stated. Solely, the author does not see the reason for this phenomenon and does not take into account the fact that in this case, we are not dealing with naive or political forms of ideology; but exactly with the political ideology in a total depth of its cynical version.

To understand such, according to P. Sloterdayk, "relativization" of the crime, and in addition, as we noted above, the double "relativization": both towards the victim and the detective; it is extremely important to build a logical movement along the "ladder". It is necessary to find out how the principal terms of our conclusion consistently followed from each other - the principal persons involved in the considered "case". 
At first, both in time and in logic, phenomenology appears - shining with the glory of German philosophy, which received the title of "classical". Here, ideology had been located inside phenomenology as a naive consciousness. Then - ideology, and shameful, starting with Napoleon and Marx, securing the title of "false, illusory" consciousness had followed. This was the birth of ideology as a political technology that has done so many things in the previous century. And only in the finale stage with the moment of exposing itself (by declaring default), at its cynical form appears.

The basic question that we have to formulate with necessity is "What in the formulation of the task of classical phenomenology was so specific, that brought about the emergence of ideology?". And, first of all, we have to find out the answer to it.

The birth of ideology. We have already paid attention to the "strange" remark of G.-H. Gadamer that, starting only with the Greeks, the humanity "noticed" the difference between a word and a thing (Kachurov,2009, p. 7). Now we have attributed this remark to the heading of oddities, taking into account the special case - the discovery that
German philosophy came across. Hegel in the introduction to his "Phenomenology ...", easily, as if for granted, states one important fact. The same distinction that consciousness itself establishes about "things for itself," we are forced to, and we cannot get anywhere from this, establish in relation to consciousness itself. This cannot be avoided just in that, and only in that case, if we make it an object for ourselves (a case of phenomenology).

This is where the concept of false consciousness first appears. It is that which is consciousness "for" the phenomenologist, in contrast to the fact that it is "for himself". This is the first meaning of ideology. Here, the "guilt" for this "falsity" lies with "für uns" (for us). But the essence of the science of phenomenology is to find out what consciousness really exists. The phenomenologist's consciousness is trying to get rid of the moment of "emergence" of consciousness as an object. In the process of clarifying this, an understanding of the experience of consciousness is formed, when, developing, consciousness passes from one of its forms into another. Only, here there is the trouble, the subsequent form does not know its origin from the 
previous one. Only the phenomenologist's consciousness knows this.

That is, it is impersonal, but not for consciousness itself (fur ihn (for him)), but for us, there is a moment of ignorance, delusion.

The consciousness of the trivial person at the beginning of European history in daily experience was immersed in the ultimate distinction between private things. "Distinguishing"; as such was entrusted to philosophy. Historical necessity should sooner or later lead it to the fact that the answer to the difference in the nature of things must be sought in the nature of consciousness. That was Kant's main concern. He even wanted to use the title of "phenomenology" in the title of the first part of his philosophy. So, one of the central defendants in our criminal novel received not only its own name but also the content.

Further, it was not difficult to predict. Unfortunately, the inventor of the harmonious word "ideology" Destutt de Trassy did not even realize that phenomenology, a little ahead of the product of his work, would be forced to apply the aforementioned "distinguishing" to consciousness. It turned out that consciousness in its experience, dealing with the "in itself and for itself" thing, itself falls under the experience of the consciousness of a phenomenologist. And there will be nothing left for him except to single out in him (after all, it is now his subject) the true (essence) of consciousness and separate from it, which is very important, consciousness as an appearance, that is, consciousness is not in itself, but consciousness for a phenomenologist. The second one - is the part that thanks to "the light hand" of K. Marx will be called the "illusory, false consciousness" of ideology.

One can speak out about ideology positively in the sense of "a totality of ordered views that express interests, etc., etc.”, one can negatively: "perverse", "turned upside down" consciousness. But its more precise definition is a form of historical being, when one consciousness exists for another consciousness. And ideology begins precisely with the very Hegelian remark that something happens behind 
the consciousness considered in phenomenology that it does not know ${ }^{16}$.

It happens that historical events are born by the will of God, it happens fate, "happens" - and by the will of an insignificant incident. But the real miracle is the birth of an event from the spirit of philosophical work, compressed into one phrase. It worth emphasizing that the following position from Hegelian phenomenology, "stuck" in the heads of the best thinkers of the nineteenth century, has caused an unprecedented phenomenon of ideology in the world history of mankind - the shibboleth of our time ${ }^{17}$.

In this significant place, namely at the end of the introduction to "Phenomenology ..." Hegel speaks of the development of his subject, which he characterizes as follows: "A new form of the existence of consciousness also appears, for which essence is something other than the previous form. It is this circumstance that directs the entire sequence of forms of the existence of consciousness in its necessity. Only this necessity itself or the emergence of a new object, which appears before the

${ }^{16}$ Here P. Ricoeur is a pure Hegelian, proposing the thesis that ideology "is a reality identified diagnostically". Psychoanalysis completely has the source of the same thought. consciousness that does not know how this happens, is that which is happening for us, as it were, behind the back of consciousness "( Hegel,2000, p. 53).

Naive ideology. In order for such consciousness to be realized that knows something, but does not know the most important, essential in itself (happening behind its "back"), there must be a consciousness that it (that which the first consciousness does not know) knows. Thus, for the relationship between these two consciousnesses, the distribution of roles must take place. One is special, the other is universal; one destiny to be limited, to another unlimited. This is phenomenology in itself. S.Zhizhek is right in asserting that "every ideology comes out immediately every time along with its criticism" («The Pervert's Guide to Cinema», Producer S. Fayns, 2006).Following from one form to another, the whole Hegelian's "ladder" of gestalt consciousness, self-awareness, and the reason is built.

It is clear that the first, conditioned consciousness of the ideologist (both the manipulated and the

\footnotetext{
${ }^{17}$ About which is easier to say than "it is not than what it is in reality" [25].
} 
manipulator), needs unconditional consciousness. In the Hegelian version: the relationship of consciousness for ourselves and consciousness for us. Naturally, the marker "for us" ("für uns") is the moment upon which the whole burden of being universal falls. For the consciousness itself, which does not know what is going on behind it, there remains a moment of easy and irresponsible being special. Here, each form of consciousness for us rises along with the steps of development. The form itself is completely lonely. For it, there is no other form, no other consciousness.

The striking dramatical effect is achieved, for example, by M. Bulgakov in the novel "The White Guard" by means of the method "consciousness for us and for ourselves", developed in phenomenology. Literary scholars pay attention to him, who seemed to have nothing to do with either philosophy or ideology. "In fact, in the novel The White Guard, we see a mirror in which there is Mikhail Bulgakov of 1918, portrayed as Alexei Turbin, and a writer of 1922. Gradually, two different "selves" of Mikhail Afanasevich led to a common denominator"'(GIPL, Moscow, p. 907. (In Russion) (1960, p. 28) S.Zhizhek, interpreting the film "Golden
Orange" by Kubrick (1971), sees the genius of Beethoven's "Ode to Joy" in this very dualism. The first part of the Ode, with sumptuous pomp, is accompanied by the second, laughing at its first part. Zhizhek calls the first pure ideology, the second - its criticism, whose task is to denounce (The Pervert's Guide to Cinema», Producer S. Fayns, 2006). Recall that Ode was written almost at the same time as Hegelian phenomenology, where in the same way one form is followed by denouncing and transition to a new one, with a new understanding of the truth and, therefore, new errors.

At the beginning of the XIX-th century ideology, indeed, behaved just like that. This is the mode of being of a naive false consciousness. We pay particular attention to the fact that here the immediacy of this consciousness consists of the ignorance of the fact that its criticism is the opposite consciousness, which "watches" it, carries out "inquiry". The first part of Beethoven's Ode is not aware of the existence of both the second part and the consciousness of the author - performer listener. The "self" of Alexei Turbin in the novel "neither in sleep nor in spirit" does not know about the "self" of 
Mikhail Bulgakov or the "self" of the reader. That is, the phenomenological consciousness reflects in the naive one, while the reverse reflection is not assumed. Did this situation changed in the early twentieth century?

The triumph of ideology. The fate of this very naive consciousness in Hegelian phenomenology was predetermined by its creator. This consciousness was originally intended to achieve the scientific consciousness of the author, climbing the ladder of limited forms; then - into the science of logic and the positive philosophy of nature and spirit.

True, there was another option: to reflect back into the consciousness of the author. Did Hegel mean it, completing his lectures on the philosophy of religion, making out the contours of the shibboleth of the coming era? (Hegel,1975, p. 333). But before we begin to interpret the very possibility of this reflection of the second stage of the existence of ideology, let us go back to the stage of its "naivety" and ask: how exactly does Hegel criticize the illusory picture of the world that every form of consciousness makes about him?

Take for example the experience of "perceiving consciousness." On the one hand, this form arose from "sensory consciousness." In this sense, perception, not knowing its origin, can be denied in terms of sensible certainty. However, the fact remains: perception is absolutely indifferent to this criticism. For him, simply there is no previous form at all!

On the other hand, the dialectic of its development will sooner or later lead to the experience of "reason" - the third form of consciousness as such. So, in a sense, the reason is also a criticism of perception. But as long as perception checks its credibility system, there is no reason for it.

Finally, on the third hand, the consciousness of a phenomenologist is an absolute critic of the ideology of perception. We, our consciousness, know everything not only about the form of perception but generally about all the steps along which consciousness ascends as a subject of phenomenology. But about him, that is, about our the writerreader, perception, while it is pure perception, it has no idea. Thus, at this first stage, ideological consciousness exists in isolation of a simple "in itself and for itself" existence. The author's consciousness reflects into it, but it responds to this with cold indifference. 
Nevertheless, even two decades have not passed since Hegel's death, how incredible happened! A clear sign of reverse reflection was the charge against philosophy itself - the very person involved, who previously spoke only in the moment "for us". The philosophy was accused of ideology - that is, that philosophy itself is a false consciousness! K. Marx and F. Engels in the middle of the XIX-th century confidently, even with some kind of barely hidden joy, they state that "now", finally: "Morality, religion, metaphysics and other types of ideology and the corresponding forms of consciousness lose their visibility of independence" (Marks, and Engel's, 1955, p. 25] ${ }^{18}$.

In 1893, F. Engels, already at the end of his life, expressed himself even more definitely on the topic of interest: "Ideology is the reflection process that the so-called thinker performs, although with consciousness, but with a false consciousness. The true motive forces that set him in motion remain unknown to him, otherwise this would not be an ideological process. Therefore, he creates for himself an idea

\footnotetext{
${ }^{18}$ Here, the classics of communism, speaking of
} false consciousness, themselves do not yet of false or seeming motivating forces "[ Yur'ev,,2007, p. 462-463).

This Engels's statement became the basis not only for all ideologies but also for all phenomenologies of the XXth century. It follows that ideology itself is "stratifying". On the one hand, negative, it remains a "representation of the false forces" that caused itself to life. On the other, positive, it can "help" a different ideology with the exposure of these forces. At the moment of the "correct" ideology, that is, its phenomenology, these two sides merge into one. This is a good example of how the final consciousness itself takes upon itself the burden of responsibility of the moment "for us" (für uns).

Here, consciousness as an object convicted by a phenomenologist of falsity, in mediating it with another consciousness, attacks the latter (in response) by indicating that together they are in fact mediated by a third one. At this point, the philosophical direction of the XX-th century deployed a whole palette of options for the specified "third" one. It is anything but consciousness itself. The above quotes from Marx and Engels are a real

realize that they are saying these on false consciousness behalf 
rebellion, a rebellion of ideology against phenomenology, in the course of which the former paradoxically reproaches the latter for ideology.

Modern scholars recall that $\mathrm{K}$. Marx rarely used the concept of "false" consciousness in relation to ideology (Ballaev,1989, p. 62). Most often, he used the term "illusory", "inverted", "consciousness turned upside down". Accordingly, the opposition to the first is "true, truthful" (which gives the case an epistemological connotation). Then the opposite of the second is "real, real." The last option, that is necessary for Marx, is considering the errors of consciousness as an ontological fact.

Within the framework of Hegelian phenomenology, this difference is not important. There, in the mentioned above introduction, the separation into "a thing in itself" ("actually") and "a thing as it seems" (a thing for consciousness) is enough. This is the famous Parmenid's separation of "knowledge" and "opinion". In the connotation of the meanings of these "distinguishes", which are primordial for European history, the procedure is mandatory for all consciousness. The one that Fichte called the "second universal foundation" self believe the non-self. But this position is impossible without the first (self=self) - the position of freedom, sovereignty, as well as the third: self $=$ not - self - the position of truth (the identity of opposites).

It is not by chance that Marx shifts the emphasis from false consciousness to illusory. Phenomenology, overturned into being, is nothing but history. But, most importantly, the fact of a "false-illusory" consciousness is simply not possible without the relationship between two consciousnesses. If you believe Gadamer that only the Greeks recognized the mentioned difference between words and things, it turns out that not a single epoch before them "recognized" in the exact sense of the word. And European history began, just like Hegelian phenomenology, with philosophical reflection into the falsity of everyday unenlightened consciousness.

Now, at the decline of this story, the reverse reflection of the falsity of the philosophical consciousness of the phenomenologist allowed one form of ideology to commit reflection into others. This is a world-wide phenomenon!

So, a hundred years after Hegel, K. Mannheim, observing the later, 
socialized forms of ideology, is forced to admit the fact that, it turns out, each of them knows about the existence of others. They peer at each other. The essence of this "peering" is that one particular form seeks to mediate itself through another. And, most importantly, each takes on a role, according to the phenomenological "breeding", criticism of all the others, that is, takes on the role of a universal form. After the "ladder" of finite forms of consciousness that do not see each other, everything changed. One illusory consciousness itself criticizes all the others. This is a political ideology that technically relates to everyday consciousness. Previously, we called this phenomenon "the ideology of modern reason” (Kachurov,1995). Yu.R. Selivanov suggests calling him "a spirit alienated from himself" (Selivanov,2005).

Of course, each political ideology seeks to acquire its own party, its own state, and form its own horizon of civilization and culture. But all this (plus, of course, the army and navy) is a means of defense, not an attack. For improvement, political ideology needs a criticism of another ideology, thanks to

19 "At least I formulate as a provocative question that it would not hurt to suspect the ideological

which her true manifestation only occurs. The natural sciences and the humanities are completely controlled by it. E.S. Lin'kov directly points to this fact in the report "What is ideology?" 19.

The keyword in the quoted fragment of "Ideology and Utopia" by K. Mannheim is a way to destroy the enemy by identifying in his ideology the moment of "conditionality by being". Naive ideology is unconditional for itself. The conditionality by our consciousness reigns in it, as we have mentioned above. In order to "break out" from this conditioning, the naive consciousness has no choice but to declare itself and other ideologies to be conditioned by being. And since there is no unconditional consciousness in the sense of immediacy, it always acts like a victim. But this is also its fault. The immediate consciousness needs to know itself conditioned.

S. Zhizhek, interpreting the mysterious duration of the fight of the protagonist of the film "Aliens Among Us" with his friend, who refuses to see things as they are (without distortion by ideology), leaves open the question: "Why does he stick to this distortion?"(

attitude of consciousness to natural phenomena" [14]. 
The Pervert's Guide to Cinema», Producer S. Fayns, 2006). But the answer is contained in this paragraph. Here we are dealing with a consciousness that wants to know itself conditioned. The ideologies of nationalism (de Gobineau and H.S. Chamberlain), communism (K. Marx and V. Lenin), and liberalism (De Tracy and K. Popper) talk about this to it. And the consciousness is flattered by these conversations.

Modern scholars correctly state this moment, uniting all political ideologies, (conditionality by being). Moreover, they correctly formulate the main problem, which will ultimately destroy this form of it. It turns out that both in the Marxist and in the postmodern tradition, the question still remains open: who should be "criticized - either the structures that determine consciousness or the consciousness itself built into these structures" (Engels,1947)? This is true. But one cannot proceed from this, because there is a "gap" in the understanding of the first and second types of ideology, plus the main question is bypassed: how could this happen?

Some believe this conditionality in national life (by origin), others - in the existence of sociohistorical formations (according to work), and others - in social and legal relations (property). But for criticizing each of them, it is necessary to show that the enemy proceeds from the conditionality of an imperfect, untrue being. As we said above, without this "initial" division into the "thing in itself" and "thing for us" (the braces that connect the entire history of Western European consciousness) you still cannot do.

Naive consciousness, aware of its mediation by being, instructs its ideology to identify for it this very conditioning. But this actually means passing the blame on to another consciousness. The latter, in turn, knowing itself as well as a conditioned being, is forced to compare itself with a different ideology (which knows the same about itself). But the comparison is not without discrimination. Both consciousnesses are united in the knowledge that being is primary, they are secondary. It seems that here the fault falls on the side of ideology. Criminal consciousness is, by definition, innocent, since it is precisely it that points to being as its primary source. The problem would be resolved here and the case 
closed, if not for the presence next to one ideology of another, with which you need to do something. One thing remains: to declare it a "true ideology." But how? Show that this consciousness is mediated by "untrue being." "Show" is easy to say. How exactly? Here a special science had to be connected, the subject of which is the difference between true and false consciousnesses. Therefore, all three political ideologies, as it were, "suddenly" recall the existence of phenomenology.

In one place $\mathrm{P}$. Sloterdayk claims that ".. criticism of ideologies is a polemic continuation of a failed dialogue by other means" (Sloterdayk,2009, p. 48). But this is not so. The opposite is more likely following from the previous analysis. Political, economic, finally, military clash of ideologies in the $\mathrm{XX}$-th century that is a "polemic" continuation of their failed dialogue by the critic through phenomenologies, when each proceeded from the primacy of being. This statement by the author of Critique of the Cynical Reason shows that he himself was captured by these very ideologies.

The last act of drama in the novel under consideration broke out before our eyes. The dialogue mentioned is a critic of the largest ideologies of the XX-th century by definition, could not be successful. The reason for this was the same thesis about the primacy of being, on the one hand, and the task of destroying the enemy by proving the total mediation of his consciousness by being, on the other. None of them could achieve their goal, because all the time each ideology's consciousness discovered that it had to build this totality by the means of consciousness itself. The bipolarity of the problem, which side exactly should be criticized: either the structures that determine consciousness or the consciousness itself built into these structures, worked in such a way that the "ball" of responsibility rolled in the opposite direction.

If, according to V. Lenin and $\mathrm{K}$. Kautsky, the enlightened, or, as they called it at the beginning of the century, "scientific," consciousness cannot be developed by the proletariat itself (read being), but can only be "brought into" it from the outside, only now the most powerful ideology is faced with a difficult test. It was necessary to try to answer the question: "Where does this most enlightened scientific consciousness come from?" If you want 
to or not, the key phrase from Hegelian phenomenology began to be recalled, which defined its task as follows: "The individual has the right to demand that science established a ladder for him, using wish he could climbed up, at least to this point of view, so that science shows him this point of view in himself "( Hegel,2000, p. 19).

That is why the complaints of naive consciousness (the victim) about the fair punishment of the ideology (criminal) of the phenomenology of the $\mathrm{XX}$-th century remind him about his own existence. The essence of this reminder briefly pointed down to an indication of freedom of choice, abandoning which the ordinary consciousness (having accepted the thesis of mediating oneself with being) made it possible to manipulate one or another ideology. But to think independently (from oneself and for oneself) is the privilege of consciousness, which constitutes the main interest of German philosophy. Does this mean a return to what it came from in the middle of the XIX-th century when the historical development sharply deviated, creating the phenomenon of ideology? So, according to the laws of the classic detective novel, it turned out at the end of the investigation that the victim was "not quite a victim".

"It is not the murderer who is guilty of the murder, but the murdered one" (Werfel). This happens in those films, at the end of which the commissar walks down the street with deep thought, making a face as if he terribly regrets that he was able to investigate this matter as well "( Sloterdayk,2009, p. 458). A similar end is a classic for a detective, but not for philosophy. We have shown how ideology was born from one exact phrase of a phenomenologist, how it grew stronger and, during its heyday, having created its own phenomenologies, contrasted itself with philosophy on all points. Ideology is a real another being of philosophy. The departure into this other being was necessary for philosophy, as well as the return. Turning philosophy inside out, political ideologies in their struggle with each other created their own phenomenologies.

Cynical ideology. Thus the "strange", final form of false consciousness appeared, either supposing its conditionality by being or removing it in the moment of returning to the idea of sovereignty. The behavior 
of false consciousness strongly resembles the lifestyle of the famous Athenian cynic Diogenes, who, with his whole philosophy, was a denial of the Athenian civilization, but at the same time, denying, could not exist without it. But if ancient cynics, as Hegel writes, "recognized independence from nature as the highest good" (Hegel,2019, p. 264), here, after all the ordeals of a naive and political form, a cynical ideology arises, declaring its highest principle independence from ideology itself. And this is a sign of the return not only of phenomenology but also of philosophy as such to its origins.

But they come back updated. Phenomenology must now understand the metamorphoses of ideological consciousness that have occurred to him over the past two hundred years. Philosophy, on the other hand, is parting with a part of knowledge about nature and spirit, which corresponds to the sphere of competence of the natural and human sciences. The certainty of phenomenology, the history of philosophy, and the science of logic remains with it. "Philosophy as a science of sciences is completed. The knowledge of the special forms of nature and the history of society is now a positive science, not a philosophy. " E.S. Linkov, the author of the above lines(Lin'kov,1997), first came to this conclusion in 1984 (Lin'kov, 1984), and P. Sloterdayk only a year earlier (1983) fixed in reality the third, final form of false consciousness - a cynical, enlightened one. This coincidence cannot be accidental. Behind it lies the most complex process of birth, flowering, and death of modern forms of ideology.

\section{CONCLUSION}

Quo vadis, Russia? Where we want to go following the mainstream of new economic and digital trends is a matter of great importance, and it has a philosophical and ethical nature. Digital technologies have begun to radically change our lives, but for some reason we rarely think about the consequences of these changes, only devoting time only to describing the tools, forgetting about the ultimate goal for which it should serve - about the new our common home that we are building today using these tools. In our common home, we should achieve complete national agreement on values, in many respects reaffirming normatively the values inherent in our civilization. 
It is at the intersection of philosophy, ethics and jurisprudence that answers to these questions should be sought, and this should be done nowadays both - as at the national, also at international levels. The new technological basis requires a new philosophy, new ethics and new political and legal mechanisms. As for the control mechanisms, they will undoubtedly be primarily technological, where the software restricts the commission of illegal actions by a person. And the philosophical, legal and ethical principles of the operation of such software should be the result of joint work and consensus of experts, as at the national, also at the international levels both.

\section{ACKNOWLEDGEMENTS}

This work was financially supported by the Russian Federation Presidential Grant No. NSh-2668-2020.6 "National-Cultural and Digital Trends in the Socio-Economic, Political and Legal Development of the Russian Federation in the 21 st Century".

\section{References}

Ballaev, A. B. "The problem of ideology in the works of Karl Marx", Istoriya filosofii, No. 3, available at : http://www.philosophy.ru/iphras/library /iph3/03.htt (accessed 12.02.2019). (In Russion) (1989),

Voronin, N. Scientific scandal of the year: scientists wrote fake studies to expose pseudo-science, available at : https:www.bbc.com/russian/features45751968 (accessed 12. 02. 2019). (In Russion)

Hegel, G. Phenomenology of the Spirit, Nauka, Moscow, p. 495. (2000),

Hegel, G. Lectures on the history of philosophy, available at : www.litres.ru/fridrih-gegel/lekcii-poistorii-filosofii/chitat-onlayn/page-4/ (accessed 28.02.2019).

Hegel, G. The philosophy of religion, Mysl', Moscow, Vol. 1-2, p. 231. (1975),

Gusserl, E. Philosophy as a strict science, available at : http://sophia.nau.edu.ua/2010-07-29-1148-45/2010-07-29-11-55-07/72-201007-31-08-38-26/ (accessed 12.02.2019). Zhizhek, S. "Vozvyshennyy ob'ekt ideologii" ["Sublime about the object ideology"], Khudozhestvennyy zhurnal, Moscow, p. 114. (1999),

«The Pervert's Guide to Cinema», Producer S. Fayns, 2006. 
Il'enkov, E. V. and Korovikov, V. I.

Passion on theses on the subject of philosophy (1954-1955), Kanon+, Moscow, p. 272. (2016),

Kachurov, E. V. "Tezis parmenida", Gumanitarniy chasopys, KhAI, Kharkiv, No. 3, p. 7. (2009),

Kachurov, E. V. Filosofiya ideologii sovremennogo rassudka The philosophy of the ideology of the modern mind, KhAI, Kharkiv, 161 p. (1995),

Korotkikh, V. I., Russian translations of the "Phenomenology of the Spirit" and the problem of the transmission of Hegelian thought in modern philosophical language, available at : https://e-

notabene.ru/fr/article_19825.html

(accessed 12.02.2019).

Korotkikh, V. I. "Phenomenology of the Spirit" and the problem of the structure of the system of philosophy in the works of Hegel, Prometey, Moscow, 383 p. (2011),

Lin'kov, E. S. What is ideology?, available at http://vispir.narod.ru/lin2.htm (accessed 12.02.2019).

Lin'kov, E. S. Formation of logical philosophy, Hegel' G.W.F. Science of Logics. Nauka, St. Petersburg, p. 800. (1997),
Lin'kov E. S. Universal dialectics as the basis and result of the relationship of thinking and being in the philosophy of Hegel", Vestnik LGU, No. 11. (1984), Lyuks, L. Two faces of totalitarianism", Istoricheskije issledovanija, No. 1, available at : http://www1.kueichstaett.de/ZIMOS/forum/Schriftenrei heRuss1.html (accessed 12.02.2019). (2014),

Manngeym, K. Ideology and Utopia, available at

file:C:/Users/sed/Downloads/105691www.libfox.ru.pdf (accessed 12.02.2019).

Marks, K. Criticism of political economy, Marks K., Engel's F. Sobranije Sochinenij, Vol. 23, GIPL, Moscow, p. 907. (In Russion) (1960), Marks, K. and Engel's, F. Collected Works, Vol. 3, GIPL, Moscow, p. 629. (In Russion) (1955),

Selivanov, Yu. R. Metod fenomenologii dukha: problemy $i$ perspektivy [Phenomenology of the Spirit Method: Problems and Prospects], available at : http://cheloveknauka.com/metodfenomenologii-duha (accessed 12.02.2019). (In Russion) (2005), Sloterdayk, P. Criticism of the cynical mind, AST M, Moscow, p. 800. (2009), 
Tinchenko, Ya.Yu., White Guard of Mikhail Bulgakov, available at : https://belaya-gvardiya-mihailabulgakova/1 (accessed 12.02.2019). (In Russion)

Engels, F. July 14, 1893, Marks K., Engel's F. Selected letters, OGIZ, Moscow, p. 536. (In Russion) (1947),

Yur'ev, R. A. The problem of ideology in the context of the phenomenological tradition], Tomsk. gos. universitet, Tomsk, available at : http://cheloveknauka.com/problemaideologii-v-kontekstefenomenologicheskoy-traditsii (accessed 12.02.2019). (In Russion) (2007),

Andreev E.M. New worldview, new ideology, and culture in the context of the processes of Eurasian integration // Social and humanitarian knowledge, 2016, No 5, p. 175.

New Philosophical Encyclopedia. M., 2010, vol. 2, p. 83.

Yakovyuk I., Shestopal, S. The sovereign rights and sovereignty of the state // Azimuth of Scientific Research: Pedagogy and Psychology. T. 6. № 4(21). PP 381-387. (2017).

Shestopal, S \& Oleynikov, S \& Yakovyuk, I. Models of the relationship between church, state and political society: Neo-Thomists' arguments. Man in India. 97. 499-508. (2017).

Bytiak, Y. P., Yakoviyk, I. V., Getman, E. A., Tragniuk, O. Y., \& Shestopal, S. S. Cooperation of former Soviet Union countries and Ukraine with the European Union. ORBIS, 14(41), 46-54. (2018). Yakoviyk, I. V., Shestopal, S. S., Baranov, P. V., \& Blochina, N. A. State sovereignty and sovereign rights: EU and national sovereignty. Opción: Revista de Ciencias Humanas y Sociales, (87), 26. (2018) 